\title{
CONTROL AND QUALITY OF PILES BY NON-DESTRUCTIVE EXPRESS METHODS: LOW STRAIN METHOD AND CROSS-HOLE SONIC LOGGING
}

\author{
Askar Zhussupbekov ${ }^{1}$, Yoshinori Iwasaki ${ }^{2}$, Eun Chul Shin ${ }^{3}$, Nurgul Shakirova $^{1}$ \\ ${ }^{1}$ L.N. Gumilyov Eurasian National University, Astana, KAZAKHSTAN \\ ${ }^{2}$ Geo-Research Institute, Osaka, JAPAN \\ ${ }^{3}$ Incheon National University, Songdo, SOUTH KOREA
}

\begin{abstract}
This paper described using Low Strain Method and Cross-Hole Sonic logging (CSL) for identify of integrity of bridge foundations of LRT in Astana, Kazakhstan. The CSL is a method prescribed by ASTM D6760 - 08, Standard Test Method for Integrity Testing of Concrete Deep Foundations. This method is considered to be more accurate than sonic echo testing in the determination of soundness of concrete. The sonic access tubes do not contribute to the structural capacity of the pile. The bored piles of LRT are $1.0 \div 1.5 \mathrm{~m}$ of diameters and $10 \div 55 \mathrm{~m}$ of lengths. Design bearing capacity of piles is more than $4500 \mathrm{kN}$. At the testing period were founded defects in foundation bodies. To check of integrity were conducted by static load tests. The CSL test is based on the length of time for an ultrasonic wave to be propagated between any two of the selected tubes. The velocity of the propagated wave depends on the material through which the wave is transmitted. The aim of this paper is to discuss the advantages and disadvantages of Low Strain Method and CSL methods by analysis of field testing. For checking integrity applying two methods - Low Strain Method and Cross-Hole Sonic Logging. The aim of this paper is to discuss the advantages and disadvantages of each method using the examples of a real application.
\end{abstract}

Keywords: Cros-hole section, PIT, integrity, concrete

\section{КОНТРОЛЬ КАЧЕСТВА СВАЙ НЕРАЗРУШАЮЩИМИ ЭКСПРЕСС-МЕТОДАМИ: МЕТОДЫ ОТРАЖЕННОЙ ВОЛНЫ ПРИ НИЗКОЙ НАГРУЗКЕ И МЕЖСКВАЖИННОЙ ДЕФЕКТОСКОПИИ}

\author{
А. Жусупбеков ${ }^{1}$, Й. Ивасаки ${ }^{2}$ Юн Чул Шин ${ }^{3}$, Н. Шакирова ${ }^{1}$ \\ ${ }^{1}$ Евразийский университет имени Л.Н. Гумилева, г. Астана, КАЗАХСТАН \\ ${ }^{2}$ Geo-Research Institute, г. Осака, ЯПОНИЯ \\ ${ }^{3}$ Incheon National University, г. Сонгдо, ЮЖНАЯ КОРЕЯ
}

\begin{abstract}
Аннотация: В данной статье представлены методы отраженной волны при низкой нагрузке и межскважинной дефектоскопии (CSL) для определения целостности мостовых фундаментов на строительной площадке LRT в Астане, Казахстан. CSL - это метод, предписанный ASTM D6760-08, Стандартный метод испытаний для проверки целостности бетонных глубоких фундаментов. Этот метод считается более точным, чем тестирование акустического эха при определении прочности бетона. Звуковые трубки доступа не влияют на структурную емкость сваи. Буронабивные сваи LRT имеют диаметр $1,0 \div 1,5$ м и длину $10 \div 55$ м. Расчетная несущая способность свай составляет более 4500 кN. На период испытаний были выявлены дефекты в фундаментах. Для проверки целостности были проведены статические нагрузочные испытания. Тест CSL основан на продолжительности распространения ультразвуковой волны между любыми двумя выбранными трубками. Скорость распространяющейся волны зависит от материала, через который она проходит. Для проверки целостности применяют два метода - метод отраженной волны при низкой нагрузке и межскважинной дефектоскопии. Целью данной статьи является обсуждение преимуществ и недостатков каждого метода с использованием примеров реального применения.
\end{abstract}

Ключевые слова: поперечное сечение, РІT, сплошность, бетон 


\section{INTRODUCTION}

At the present time, in Astana city is going on works by construction public transport system LRT (Light Railway Transport). The first stage of construction is including construction of overhead road (bridge) with 22,4 km length and 18 stations. Height of the bridge is $7 \div 14 \mathrm{~m}$ above the ground. Overhead road based on columns every 30 meters. The foundation of each column is include 4 or 6 bored piles with cross-section $1.0 \div 1.5 \mathrm{~m}$ and length $8 \div 55 \mathrm{~m}$. Design bearing capacity of each bored piles is from 4500 to $12000 \mathrm{kN}$.

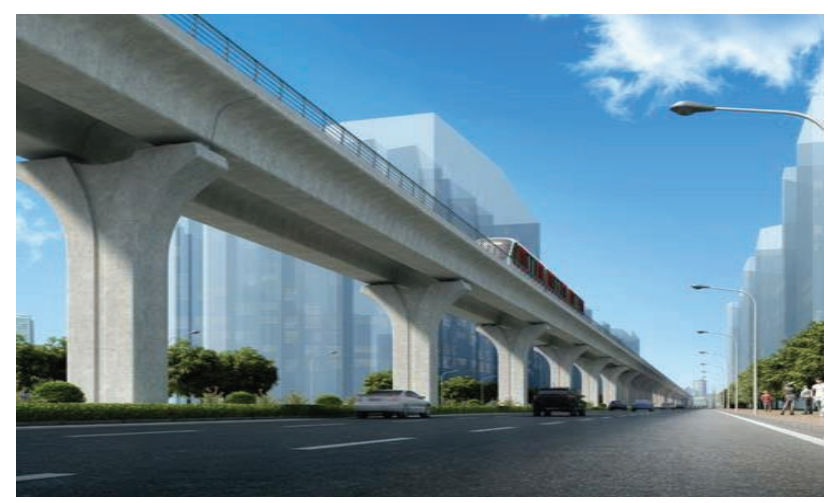

Figure 1. Perspective view of LRT, Astana, Kazakhstan.

In order to reduce the time for construction and cost of piling works Chinese companies are use Chinese drilling rigs Zoomlion without casing. To maintain the walls of boreholes in sand and gravel soils using polymer slurry. Application of polymer slurry allow reducing time for drilling, allow to use less powerful drilling rigs and equipment, but at the same time increase the risk of collapsing soil during drilling or concreting piles. In these conditions, very important to control integrity of concrete body of each bored piles. For checking integrity of bored piles applying two methods - Low Strain Method and Cross-Hole Sonic Logging.

\section{INTEGRITY TESTING}

Everybody with experience in reinforced concrete construction has encountered columns that, upon dismantling of the forms, exhibit air voids and honeycombing. Although these columns may have been cast with good-quality concrete, in properly assembled forms and with careful vibration, they still exhibit defects. Castin-situ piles are also columns, but instead of forms made of wood or metal we have a hole in the ground. This hole may pass through layers of dumped fill, loose sand, organic matter, and ground water, which may be fast flowing or corrosive. Obviously, such conditions are not conducive to a high-quality end product. The fact that on most sites we still manage to get excellent piles is only a tribute to a dedicated team that makes this feat possible: geotechnical engineer, structural engineer, quantity surveyor, contractor, site supervisor and quality control laboratory. This is obviously a chain, the strength of which is determined by the weakest link [7].

A flaw is any deviation from the planned shape and/or material of the pile. A comprehensive list of events, each of which can lead to the formation a flaw in a pile: use of concrete that is too dry, water penetration into the borehole, collapse in soft strata, falling of boring spoils from the surface, tightly-spaced rebars etc.

Therefore, we have to face the fact that on any given site some piles may exhibit flaws. Of course, not all flaws are detrimental to the performance of the pile. Only a flaw that, because of either size or location, may detract from the pile's load carrying capacity or durability is defined as a defect. The geotechnical engineer and the structural engineer are jointly responsible to decide which flaw comprises a defect.

The two techniques currently dominating pile integrity testing, namely the Low Strain Method and Cross-Hole Sonic Logging, both utilize sound waves (Amir et al 2009).

\section{Low Strain Method.}

The low strain (sonic) method for the integrity testing of piles is aimed at routinely testing complete piling sites. To perform this test, a sensor (usually accelerometer) is pressed against 
the top of the pile while the pile is hit with a small hand-held hammer. Output from the sensor is analyzed and displayed by a suitable computerized instrument, the results providing meaningful information regarding both length and integrity of the pile.

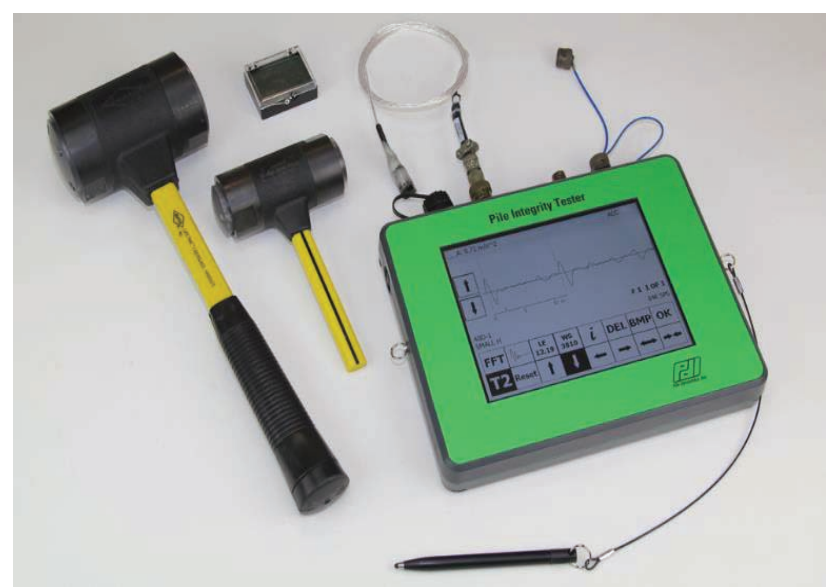

Figure 2. Pile Integrity Tester - PIT-QV.

The sonic test is fast and inexpensive, with less than a minute needed to test a given pile.

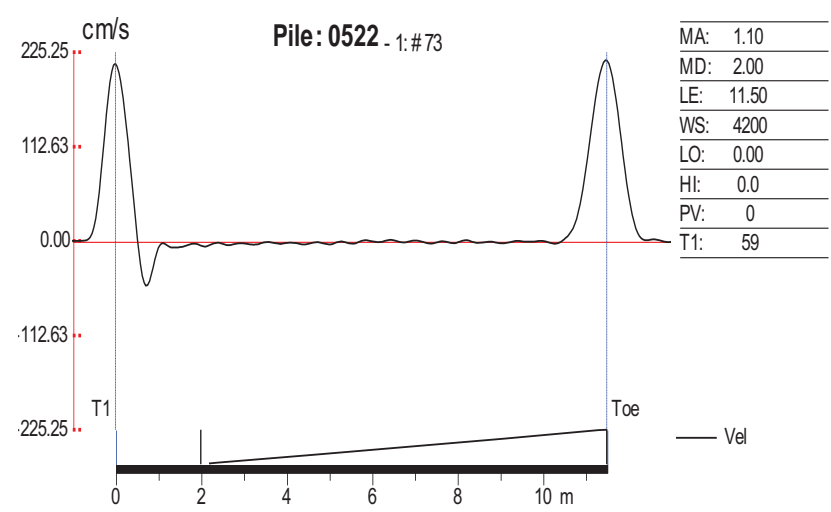

Figure 3. Example of normally result graph ("good" pile).

The surface vibrations are measured by means of an accelerometer attached to the top of the pile. Although the acceleration curve could be interpreted directly, integration to velocity generally enhances the record by bringing out details otherwise overlooked. The pile top acceleration signal, is therefore digitized and stored in the PIT device memory, and it is numerically integrated to produce a velocity signal. It should be noted that $\mathrm{v}$ is a particle velocity, i.e., the actual velocity of movement of the pile top surface.

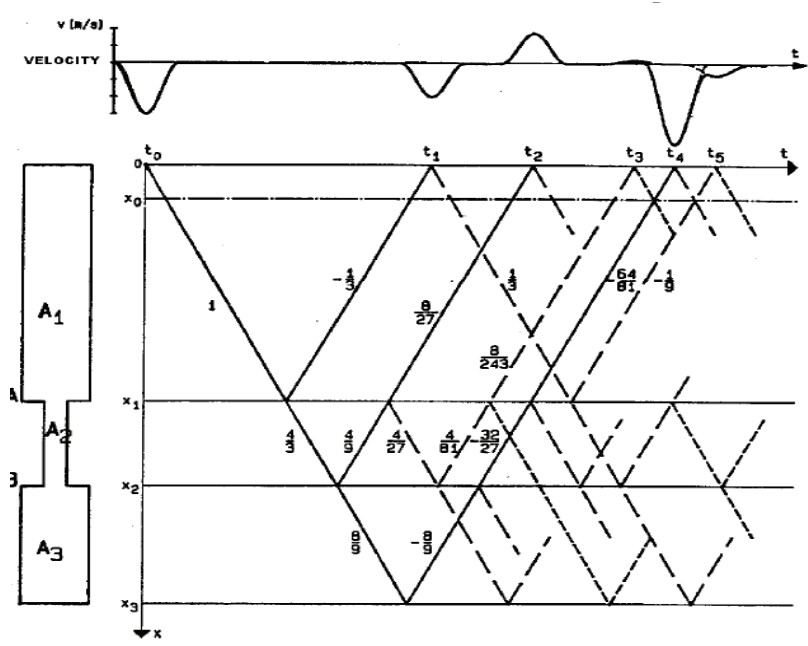

Figure 4. Characteristics for a rod with a reduced cross-section $(A 2=A 1 / 2, A 3=A 1)$.

\section{Wave Speed in Concrete.}

The Impact wave speed in concrete depends on the quality of the concrete and for in-situ casted piles the curing time of the concrete. The wave speed is used to determine the length of the pile based on the return signal. An example of the wave speed in concrete is shown below.

Table 1. Soil Properties Used in Analysis.

\begin{tabular}{|c|c|}
\hline Concrete quality & $\begin{array}{c}\text { Impact wave speed } \\
(\mathbf{m} / \mathbf{s})\end{array}$ \\
\hline Bad & $<2.700$ \\
\hline Acceptable & $2.700-3.300$ \\
\hline Good & $3.300-3.800$ \\
\hline Very good & $3.800-4.000$ \\
\hline Excellent & $4.000-4.500$ \\
\hline $\begin{array}{c}\text { Unlikely Normal } \\
\text { Conditions }\end{array}$ & $>4.500$ \\
\hline
\end{tabular}

\section{Interpretation results obtained by Low Strain Method.}

An assessment by this method can give a rapid and accurate appraisal of pile integrity. An integrity test will indicate when a pile should be investigated further but it cannot give information about any load carrying capacity of the pile. 
Interpretation of the results obtained must take into account the specific pile circumstances, i.e. construction technique and localized soil conditions. An anomaly does not necessarily indicate a deficiency in the pile, but would certainly merit further investigation to establish the cause of the anomaly. Full interpretation of the signal responses must only be undertaken by fully trained personnel.

For interpretation ten classes are distinguished:

\section{Low Strain Testing Constraints.}

The following items may often be detected:

- Pile length.

- Inclusions of foreign material with different acoustic properties.

- Cracking perpendicular to the axis.

- Joints and staged concreting.

- Abrupt changes in cross section.

- Distinct changes in soil layers.

All physical measurements have limitations, and low strain (sonic) test probably has more limitations than any other test. For instance, the sonic test will normally not detect the following items:

- The toe reflection when the $\mathrm{L} / \mathrm{D}$ ratio roughly exceeds 20 (In hard soils) to 60 (In very soft soils).

- Gradual changes in cross-section.

- Minor inclusions and changes in crosssection.

- Impedance changes of small axial dimension.

- Small variations in length.

- Features located below either a fully-cracked cross section or a major (1:2) change in impedance.

- Debris at the toe.

- Deviations from the straight line and from the vertical.

- Load-carrying capacity.

- The consistency of concrete cover.

- The length of reinforcement.

\section{Cross-Hole Sonic Logging.}

"Crosshole Sonic Logging" (CSL) is a testing method for the determination of pile integrity in accordance with relative change of such acoustic parameters as sonic time, frequency and amplitude attenuation when actual measured sound wave transmitted in the concrete media, shooting and receiving sound waves among preburied sonic-testing tubes of the pile (ASTM D6760 - 08 (2008)).

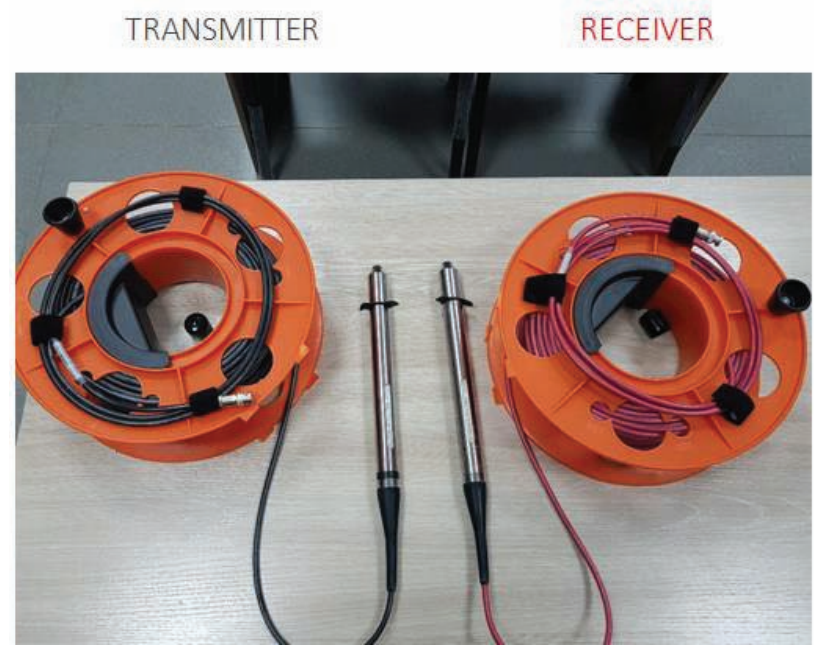

Figure 5. Transmitter and Receiver Probes.

The Low Strain method belongs to the external test-methods, as it accesses only the top of the pile. Ultrasonic logging, on the other hand, is intrusive and necessitates the prior installation of access tubes (usually two or more) in the pile.

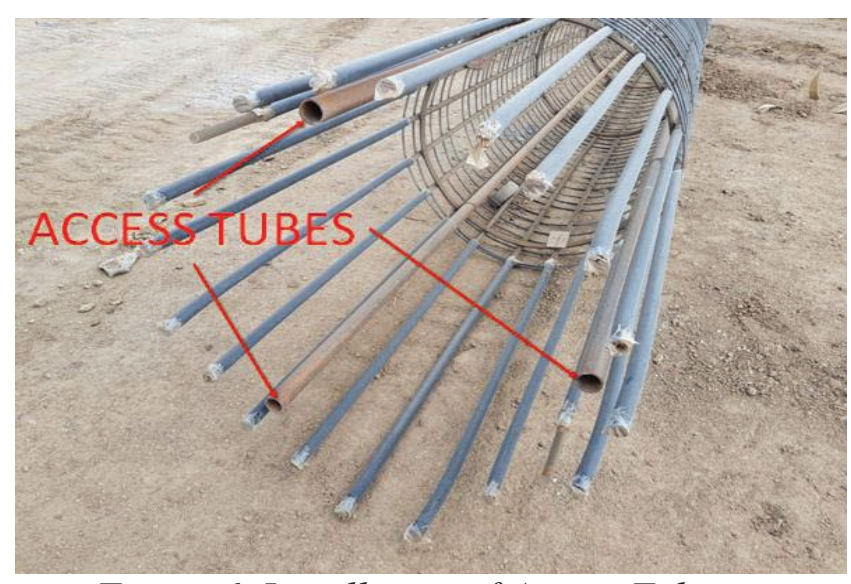

Figure 6. Installation of Access Tubes.

Before the test they have to be filled with water (to obtain good coupling) and two probes are lowered inside two of the tubes. One of these probes is an emitter and the other a receiver of ultrasonic pulses. Having been lowered to the 
bottom, the probes are then pulled simultaneously upwards to produce an ultrasonic logging profile. The transmitter produces a series of acoustic waves in all directions. Some of these waves do eventually reach the receiver.

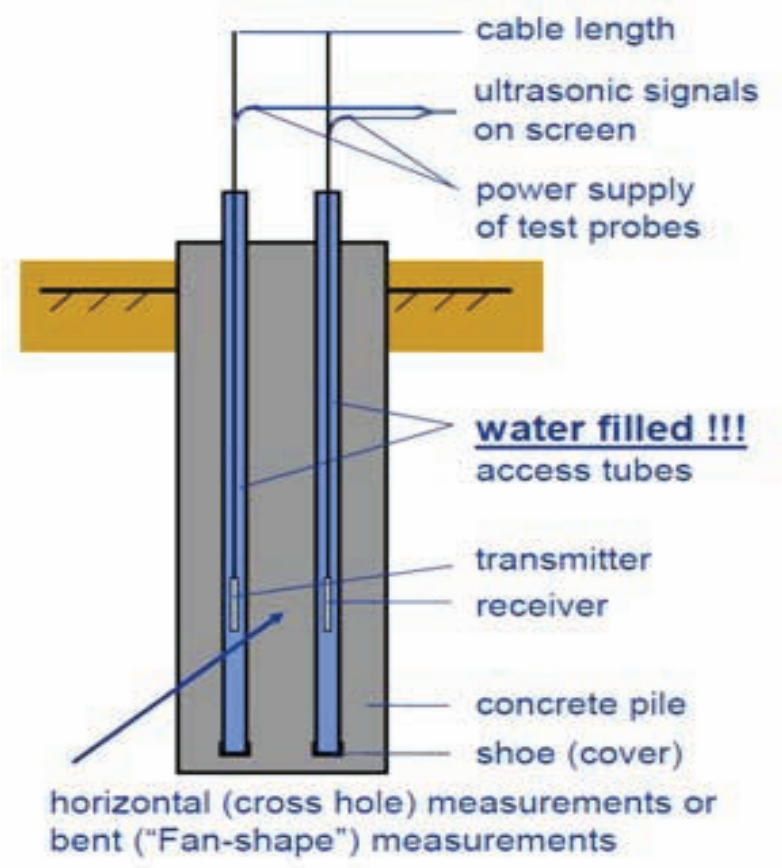

Figure 7. Cross-Hole Sonig Logging - Principle.

The testing instrument then plots the travel time between the tubes versus the depth. As long as this time is fairly constant, it shows that there is no change in concrete quality. A sudden increase of the travel time at any depth may indicate a flaw at this depth.

The number of access tubes cast in the pile concrete is a function of the pile diameter, the importance of the pile and, of course, economic consideration. A good rule of thumb is to specify one tube per each $30 \mathrm{~cm}$ of pile diameter. Thus for a pile with a diameter of $1.2 \mathrm{~m}$, four tubes will normally do. For best effect, the tubes should be equally spaced inside the spiral reinforcement and rigidly attached to it by wire or spot welding. Where tubes are extended below the reinforcement cage, they have to be stabilized by suitable steel hoops.
Cross-Hole Sonic Logging Results.

Usually the report includes presentation of Cross-Hole Sonic logs for all tested tube pairs including:

- Presentation of the traditional signal peak diagram as a function of time plotted versus depth.

- Computed initial pulse arrival time or pulse wave speed versus depth.

- Computed relative pulse energy or amplitude versus depth.

A Cross-Hole Sonic log will be presented for each tube pair. Defect zones, if any, will be indicated on the logs and their extent and location discussed in the report text. Defect zones are defined by an increase in arrival time of more than 20 percent relative to the arrival time in a nearby zone of good concrete, indicating a slower pulse velocity.

\section{Tomography by the data of Cross-Hole Sonic Logging.}

The same procedure, which is carried out in two dimensions on a single profile, can be used in three dimensions for the whole pile. In this case, the pile is divided into elementary voxels, or volume pixels, this process is usually called a tomography.

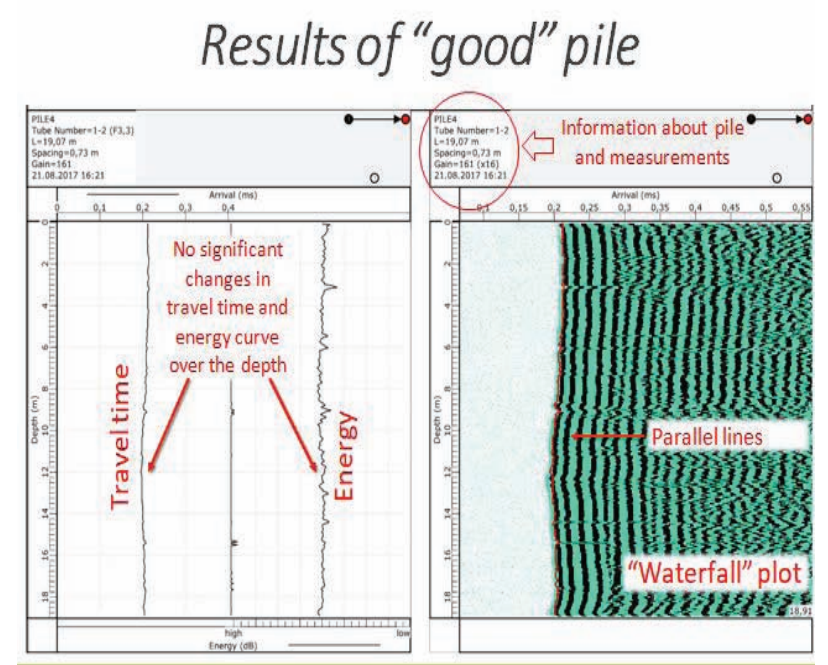

Figure 8. Typical Ultrasonic Profile. 


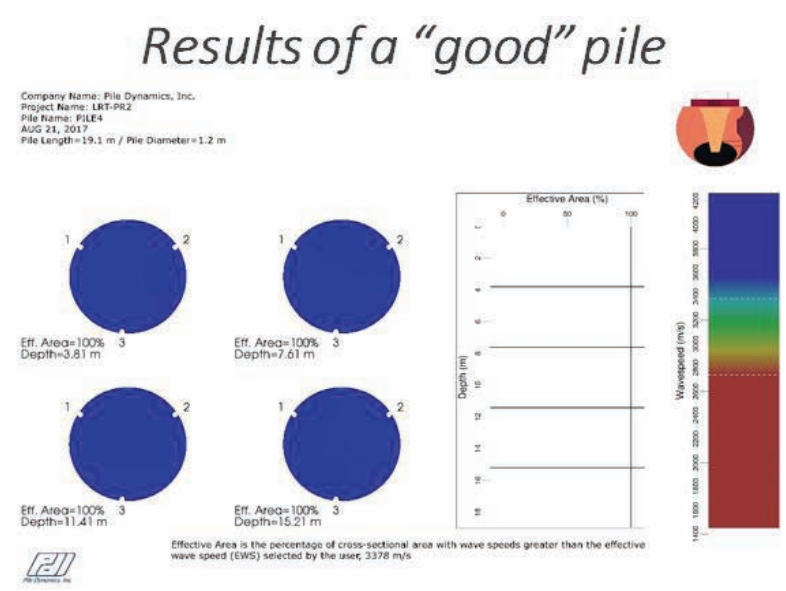

Figure 9. Horizontal cross-sections of pile in PDI-TOMO software.

Tomography is a mathematical procedure that is applied to Crosshole Sonic Logging (CSL) data, providing the user with a visual image of a shaft's internal defects. The procedure involves solving a system of equations based on First Arrival Times (FAT) in order to calculate wave speeds at various points within the shaft. Tomography wave speeds distributed throughout the shaft are directly proportional to density, indicating concrete quality. PDI-TOMO is an extension of the CHA-W software designed for superior tomographic analysis results from CHAMP data with increased efficiency for the user.

\section{Results of "good" pile}

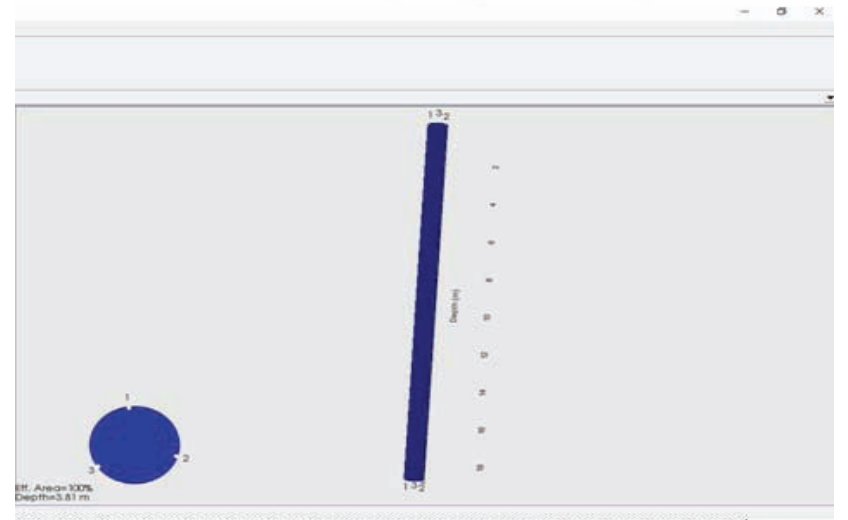

Figure 10. Three-dimensional visualization in PDI-TOMO software.

PDI-TOMO software features:

- Provides a more precise location, shape and size of defective areas within a shaft.
- Offers an intuitive visual identification of the damaged areas and generates easily comprehensible and professional outputs for the consumer of the CSL reports.

- Provides a valuable add-on service for the testing engineer.

\section{Cross-Hole Sonic Testing Constraints}

The Cross-Hole Sonic Test will normally detect the following items:

- Finds multiple defects, depth and quadrant.

- Finds "soft bottoms" if tubes go to bottom.

- Finds voids better than soil inclusions.

- Finds larger defects easier than small defects.

- Waterfall, FAT (First arrival time), \& energy all help find defect.

- Not sensitive to surrounding soils or pile length.

The Cross-Hole Sonic Test will normally not detect the following items:

- Cannot find diameter changes or bulges.

- If too few tubes, can miss a defect.

- Can find defect on direct path.

- Cannot find defect outside cage.

- Major diagonal defects more difficult to find.

- Need more than 4 tubes for $1500 \mathrm{~mm}$ pile (recommend 6 tubes for shaft this size).

\section{Comparison test results obtained by two methods.}

In 2017-2018 at the construction site of LRT in Astana city, more than 1500 bored piles were integrity tested by using two methods: $45 \%$ by Cross-Hole Sonic Logging and other $55 \%$ by Low Strait Test. Client gives a technical assignment for integrity testing piles:

- if one foundation of the bridge consists of four bored piles, then one pile is tested by CrossHole Sonic Logging and other three piles tested by Low Strait Test.

- if one foundation of the bridge consists of six bored piles, then two pile is tested by CrossHole Sonic Logging and other four piles tested by Low Strait Test.

One of the tested pile PR16-2 contained a serious defect of integrity. 
Control and Quality of Piles by Non-Destructive Express Methods: Low Strain Method and Cross-Hole Sonic Logging
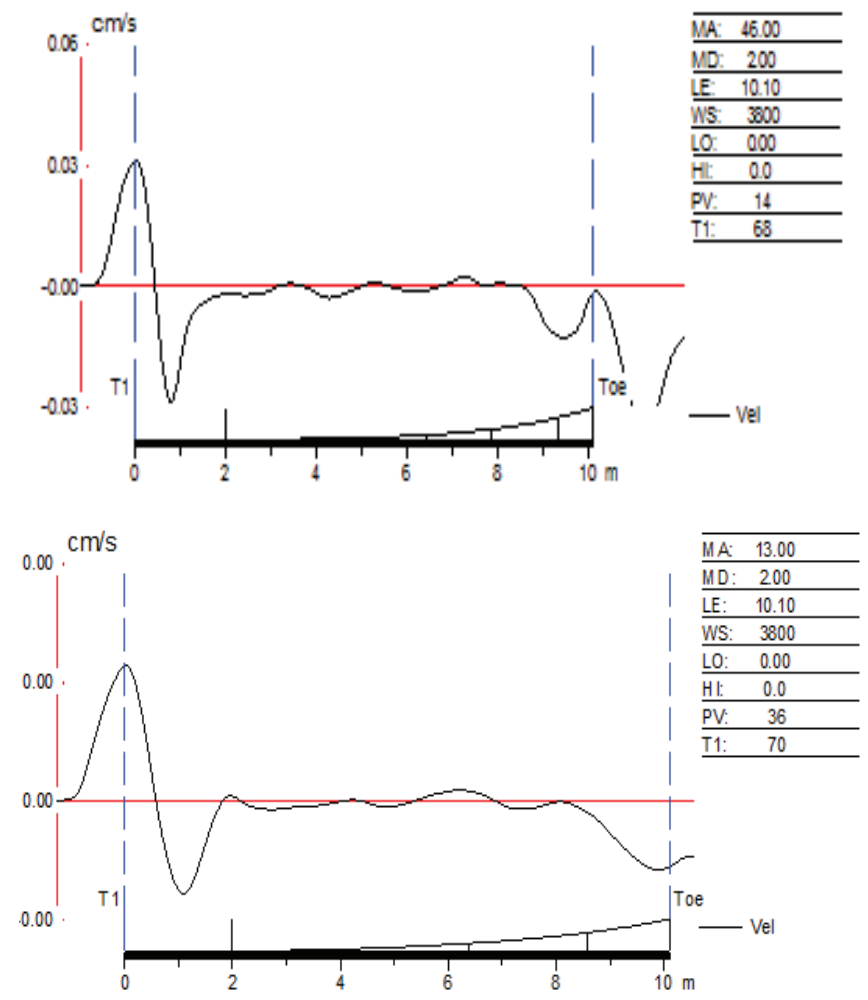

Figure 11. Two reflectograms of one bored "bad" pile PR16-2 obtained by Pile Integrity Tester - PIT-QV.

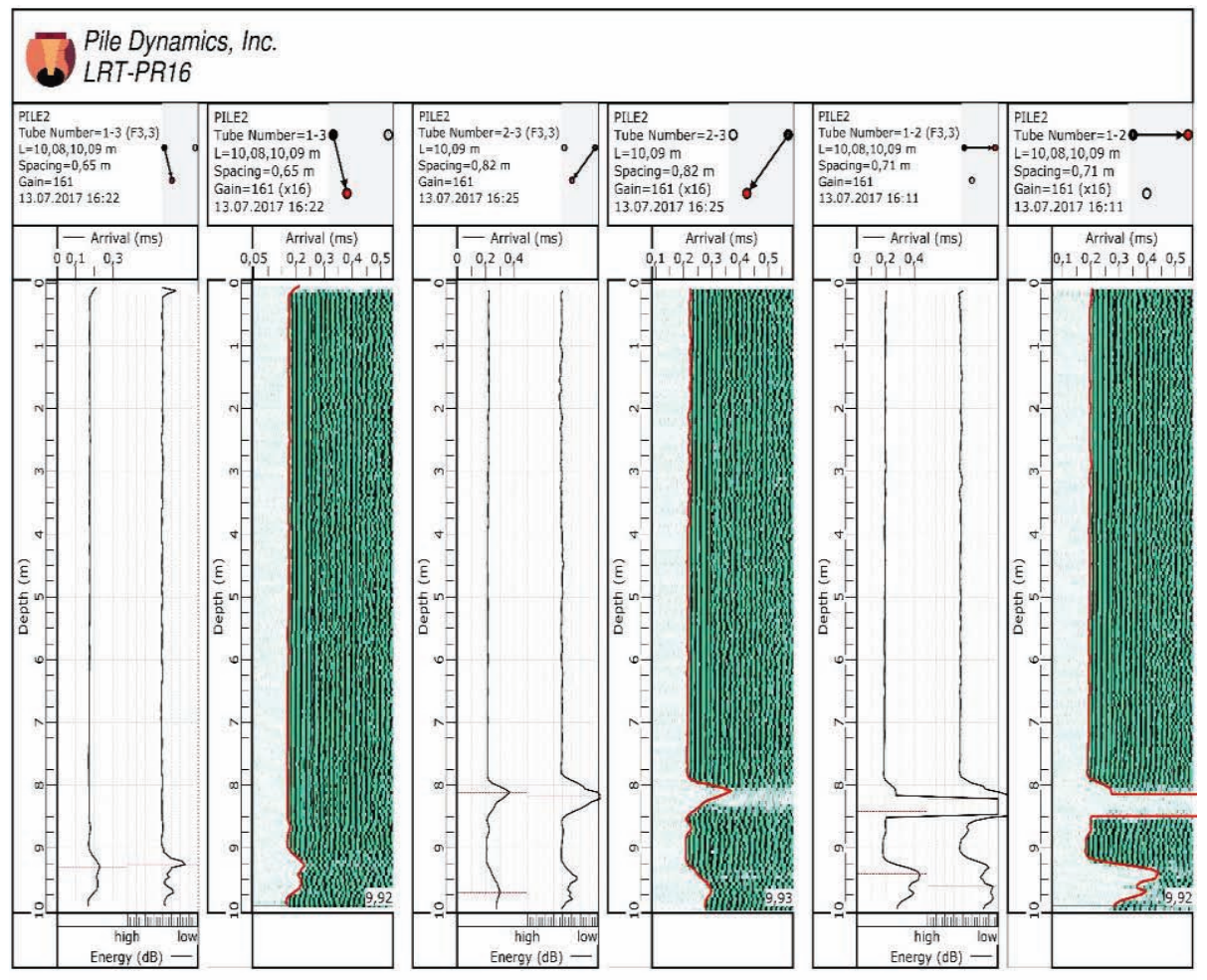

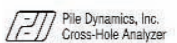

$1 / 1$

Figure 12. Three Ultrasonic Profile of one pile PR16-2 ("bad" pile). 


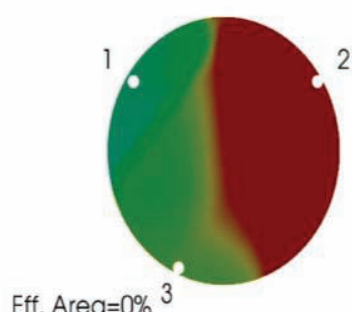

Depth=8.12 m

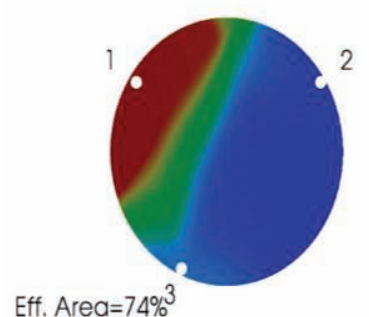

Depth $=9.25 \mathrm{~m}$

Figure 13. Horizontal cross-sections of pile PR16-2 in PDI-TOMO software.

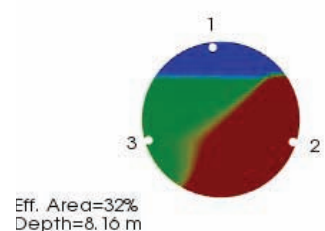

Figure 14. Three-dimensional visualization in PDI-TOMO software for bored pile PR16-2.

Analyzing the data obtained by Low Strain Test (Fig. 11) we can say only that at the depth $8.5 \mathrm{~m}$ this pile has crack and its cross-section is decreasing.

Analyze the data of Cross-Hole Sonic Test can show 3D location of cracks, approximately size of cracks, effective cross-section of pile at any depth. Cross-Hole Sonic Test provide more useful information about integrity and allows the engineer to evaluate the seriousness of the problem and the possibility of using this pile in foundation.

\section{CONCLUSIONS}

At the final consideration on results of CSL testing presented following concluding remarks: the defects are had different issues as well as low quality of concrete (strength is not reach to the project), non-observance of the work of production technology or soil ingress into the concrete pouring into the drilling shaft. Also big influence was affected the soil condition of construction site. The Cross-hole logging testing is most accurately and quality for field observation of deep pile foundations. Since resolution is strongly dependent on the wave length, the cross-hole method enables us to detect much smaller flaws with high accuracy.

The Pile Integrity Tester (PIT) is an instrument for integrity testing of foundations by low-strain surface-impact methods. The Low Strain test is a powerful quality-control tool, not so expensive and need about one minute for application but we must never forget that it is not omnipotent. Since the sonic method is based on the use of stress-waves, it can identify only those pile attributes that influence wave propagation and have a fairly large size. Data collected by the PIT can and should be further analyzed using the PIT-W software for a more thorough data interpretation and report quality output.

\section{REFERENCES}

1. Joram M.A. Pile Integrity Testing, Israel, 2009.

2. ASTM Standard D. Standard Test Method for Low Strain Impact Integrity Testing of Deep Foundations. ASTM International, West Conshohocken, PA, 2000.

3. ASTM Standard D 6760. Standard Test Method for Integrity Testing of Concrete Deep Foundations by Ultrasonic Crosshole 
Testing. ASTM International, West Conshohocken, PA, 2002.

4. White B., Nagy M., Allin R. Comparing Cross-Hole Sonic logging and Low-Strain Integrity Testing Results. // Proceedings of the 8th International Conference of Application of Stress Wave Theory to Piles, Lisbon, 2008, pp. 471-476.

5. Bungenstab F.C., Beim J.W. Continuous Flight Auger (CFA) Piles - A Review of the Execution Process and Integrity Evaluation by Low Strain Test. Buenos Aires, Argentina, IOS Press, 2015, pp. 414421.

6. Massoudi N., Teferra W. Non-Destructive Testing of Piles Using the Low Strain Integrity Method. // Proceedings of the Fifth International Conference on Case Histories in Geotechnical Engineering, New-York, NY, 2004, pp. 1-6.

7. Zhussupbekov A., Iwasaki Y., Omarov A.R. The Experience Different of Piling Testing on Problematical Soil Ground of Astana, Kazakhstan. // International Journal for Computational Civil and Structural Engineering, 2018, Volume 14, Issue 4, pp. 158-171.

\section{СПИСОК ЛИТЕРАТУРЫ}

1. Joram M.A. Pile Integrity Testing, Israel, 2009.

2. ASTM Standard D. Standard Test Method for Low Strain Impact Integrity Testing of Deep Foundations. ASTM International, West Conshohocken, PA, 2000.

3. ASTM Standard D 6760. Standard Test Method for Integrity Testing of Concrete Deep Foundations by Ultrasonic Crosshole Testing. ASTM International, West Conshohocken, PA, 2002.

4. White B., Nagy M., Allin R. Comparing Cross-Hole Sonic Logging and Low-Strain Integrity Testing Results. // Proceedings of the 8th International Conference of
Application of Stress Wave Theory to Piles, Lisbon, 2008, pp. 471-476.

5. Bungenstab F.C., Beim J.W. Continuous Flight Auger (CFA) Piles - A Review of the Execution Process and Integrity Evaluation by Low Strain Test. Buenos Aires, Argentina, IOS Press, 2015, pp. 414421.

6. Massoudi N., Teferra W. Non-Destructive Testing of Piles Using the Low Strain Integrity Method. // Proceedings of the Fifth International Conference on Case Histories in Geotechnical Engineering, New-York, NY, 2004, pp. 1-6.

7. Zhussupbekov A., Iwasaki Y., Omarov A.R. The Experience Different of Piling Testing on Problematical Soil Ground of Astana, Kazakhstan. // International Journal for Computational Civil and Structural Engineering / Международный журнал по расчету гражданских $и$ промышленных конструкиий, 2018, Volume 14, Issue 4, pp. 158-171.

Askar Zhussupbekov, Professor, Dr.Sc., Head of Department of Civil Engineering, L.N. Gumilyov Eurasian National University; 13a, Kazhimukan st., Astana, Republic of Kazakhstan, 010010; phones +7 (7172) 344796 (office),

+7(7015) 118382 (mobile); fax +7 (7172) 709457;

E-mail: enu@enu.kz.

Yoshinori Iwasaki, Professor, Ph.D., Executive Director, Geo-Research Institute; Invited Professor, L.N. Gumilyov Eurasian National University; Honorary Professor, SaintPetersburg State University of Architecture and Civil Engineering; 4-3-2 Itachi-bori, Nishi-ku, Osaka 550-0012, Japan; phones +81-6-6941-8800 (office), +81-90-8938-

1191 (mobile); fax +81-6-6941-8882;

E-mail: yoshi-iw@geor.or.jp.

Eun Chul Shin, Department of Civil and Environmental Engineering, Incheon National University; 119 Academyro, Songdo 1(il)-dong, Yeonsu-gu, Incheon, South Korea.

Nurgul Shakirov, Department of Civil Engineering, L.N. Gumilyov Eurasian National University; 13a, Kazhimukan st., Astana, Republic of Kazakhstan, 010010; phones +7(7172) 344796 (office); fax 7 (7172) 709457; E-mail: enu@enu.kz. 
Жусупбеков Аскар Жагпарович, профессор, доктор технических наук, заведующий кафедрой Проектирование зданий и сооружений», Евразийский национальный университет им. Л.Н. Гумилева; председатель ТC 305 (ISSMGE); президент Казахской геотехнической ассоциации; 010010, Казахстан, г. Астана, ул. Кажымукана 13a; тел.: +7(7172) 344796 (рабочий), +7(7015) 118382 (мобильный);

факс+7 (7172) 709457; E-mail: enu@enu.kz.

Ивасаки Йошинори, профессор, доктор философии (Ph.D.); исполнительный директор, Геоисследовательский институт; председатель АТC 19 Геопамятники культурного наследия (ISSMGE); приглашенный профессор, Евразийский национальный университет им. Л.Н. Гумилева; Почетный профессор Санкт-Петербургского государственного архитектурно-строительного университета; 2-1-2, Отамае, Чуо-ку, Осака 540-008, Япония; тел.: +81-6-6941-8800 (рабочий),

+81-90-8938-1191 (мобильный);

факс+81-6-6941-8882; e-mail: yoshi-iw@geor.or.jp.

Юн Чул Шин, факультет гражданского и экологического строительства, Национальный университет Инчхон, Сонгдо, Южная Корея; 119 Academy-ro, Songdo 1(il)-dong, Yeonsu-gu, Incheon.

Нургул Шакиров, кафедра Проектирование зданий и сооружений», Евразийский национальный университет им. Л.Н. Гумилева; 010010, Казахстан, г. Астана, ул. Кажымукана 13a; тел.: +7(7172) 344796 (рабочий); факс +7 (7172) 709457; E-mail: enu@enu.kz. 